\title{
Identification and Classification of Pathogenic Bacteria Using the K-Nearest Neighbor Method
}

\section{Identifikasi Dan Klasifikasi Bakteri Patogen Dengan Metode K-Nearest Neighbour}

\author{
Diana Rahmawati ${ }^{1)}$, Mutiara Puspa Putri I'), Miftachul Ulum ${ }^{3)}$, Miftachul Ulum ${ }^{4)}$ \\ ${ }_{1,2,3,4)}$ Departement Electrical Engineering, Trunojoyo University Madura, Indonesia \\ 1) diana.rahmawati@trunojoyo.ac.id \\ ${ }^{2}$ mutiarapuspa07@gmail.com \\ 3) miftachul.ulum@trunojoyo.ac.id
}

\begin{abstract}
Bacteria are a group of living things or organisms that do not have a core covering. In the grouping, some bacteria are pathogenic. With a microscopic size, many pathogenic bacteria are found around and spread through the food eaten or by touching objects around them, then cause diseases such as diarrhea, vomiting, and others. As a more effective effort to help the government and society prevent disease caused by pathogenic bacteria, a system for the identification and classification of pathogenic bacteria K-Nearest Neighbor was created. This system uses a biological microscope that is attached to a webcam camera above the ocular lens as a tool to see bacterial objects and assist in bacterial capture. Rough player rotates automatically (auto-focus) in image capture. In the process of classification and identifying bacteria, the K-Nearest Neighbor method is used, which is a method with the calculation of the nearest neighbor or calculation based on the level of similarity to the dataset. In this study, the bacteria vibrio chlorae, staphylococcus aereus, and streptococcus $\mathrm{m}$. with the highest accuracy is the $\mathrm{K}=9$ value of $97.77 \%$ using the Chebyshev method.
\end{abstract}

Keywords : Classification; Identification; Pathogen; K- Nearest Neighbor; Chebyshev.

Abstrak-. Bakteri merupakan salah satu golongan makhluk hidup atau organisme yang tidak memiliki selubung inti. Dalam pengelompokannya, beberapa bakteri besifat patogen. Dengan ukuran mikroskopis, bakteri patogen banyak terdapat di sekitar dan menjangkit melalui makanan-makanan yang dimakan atau sentuhan pada benda disekitar, kemudian menyebakan penyakit seperti diare, muntah, dan lainnya. Sebagai upaya yang lebih efektif untuk membantu pemerintah dan masyarakat mencegah terjangkit penyakit yang disebabkan oleh bakteri patogen dibuatlah sistem identifikasi dan klasifikasi bakteri patogen $K$ - Nearest Neighbour. Sistem ini menggunakan mikroskop biologi yang dipasang kamera webcam diatas lensa okulernya sebagai alat untuk melihat objek bakteri dan membantu dalam capture bakteri. Pemutar kasar berputas secara otomatis (auto-focus) dalam pengambilan citra. Pada proses klasifikasi dan mengidentifikasi bakteri digunakan metode $K$-Nearest Neighbour yaitu sebuah metode dengan perhitungan tetangga terdekat atau perhitungan berdasarkan tingkat similaritasnya dengan dataset. Pada penelitian ini digunakan bakteri vibrio chlorae, staphylococcus aereus, dan streptococcus $m$. dengan akurasi paling tinggi adalah nilai $\mathrm{K}=9$ sebesar $97.77 \%$ menggunakan metode Chebyshev.

Kata kunci : Klasifikasi; Identifikasi; Patogen; K- Nearest Neighbour; Chebyshev. 


\section{$\sqrt{7} \sqrt{4} \pi 7$ Journal of Electrical and Electronic Engineering-UMSIDA ISSN 2460-9250 (print), ISSN 2540-8658 (online)

\section{PENDAHULUAN}

Bakteri merupakan salah satu golongan makhluk hidup prokariotik (organisme yang tidak memiliki selubung inti) [1]. Dalam pengelompokannya, beberapa bakteri besifat patogen. Patogen berasal dari bahasa yunani yang berarti agen biologis atau mikroorganisme yang menyebabkan penyakit pada inangnya. Sehingga merugikan makhluk hidup lain yang menjadi inangnya salah satunya manusia. Dengan ukuran mikroskopis, bakteri patogen banyak terdapat di sekitar dan menjangkit melalui makananmakanan yang dimakan. Salah satunya adalah bakteri Staphylococcus aereus yang terdapat pada benda-benda di sekitar kita dan tak kasat mata. Bakteri ini sering dikaitkan terhadap beberapa penyakit seperti dermatitis dan infeksi saluran pernafasan. Sistem ini bekerja untuk membantu mempercepat proses pengklasifikasian dan mengidentifikasi sebuah bakteri menggunakan metode klasikasi K-Nearest Neighbour dan auto-focus pada pemutar kasarnya.

\section{METODE PENELITIAN}

Dalam perancangannya, sistem ini dibagi menjadi dua perancangan, yaitu perancangan perangkat lunak dan rancangan perangkat keras sesuai dengan blok diagram gambar 1 dibawah ini.

\section{[Figure 1 about here.]}

\subsection{Perangkat lunak}

Perancangan perangkat lunak pada penelitian terdapat beberapa sistem, yaitu sistem image preprocessing untuk memperbaiki citra asli koloni bakteri, image preprocessing dan sistem klasifikasi bakteri menggunakan $K$ Nearest Neighbour.

[Figure 2 about here.]

Sistem ini dimulai dari pengambilan citra dari mikroskop untuk memperoleh capture bakteri melalui kamera webcam. Dalam proses ini dilakukan pemilihan kualitas capture terbaik. Hasil capture dari mikroskop kemudian selanjutnya dipergunakan untuk image preprocessing. Image preprocessing sangat penting dilakukan pada penelitian ini untuk mendapat kualitas citra terbaik sebelum dilakukan klasifikasi.

\section{[Figure 3 about here.]}

Proses Contrast Stretching (normalisasi) merupakan suatu teknik perbaikan kualitas citra yang cukup sederhana dengan meningkatkan kontras citra. Agar citra semakin baik dilakukan filter image. Filtering adalah teknik untuk menyaring atau memodifikasi untuk meningkatkan kualitas citra gambar. Pada filter image kali ini menggunakan pyramid mean shift. Algoritma pada pyramid mean shift menggunaakan teknik analisis nonparametric feature space. Metode ini merupakan prosedur dalam melacak atau menghitung objek berdasarkan yang paling sering keluar. Algoritma mean shift menggunakan perhitungan kernel density. Citra grayscale digunakan untuk menyederhanakan citra untuk input proses selanjutnya. Kemudian menggunakan metode thresholding merupakan metode sederhana dari image segementation. Thresholding merupakan operasi non-linear yang mengkonversi sebuah grayscale image menjadi binary image. Pada proses ini dilakukan pemisahan objek koloni dengan background. Setelah pada thresholding beberapa citra akan hilang. Makan diperlukan untuk mendeteksi object menggunakan contour kemudian dilakukan labelled image. Pada proses ini teknik contour digunakan untuk menemukan object yang sama dalam satu picture lalu diberikan label untuk menandai bakteri apa yang terdapat pada picture tersebut. Setelah dideteksi adanya bakteri pada preparat tersebut dan memberikan label. Dilakukan perhitungan sesuai contour dan label yang ada dalam gambar tersebut sesuai parameter yaitu roundness menemukan jenis bentuk bakteri yang sesuai, boundering untuk keliling dari object, kemudian colony counter untuk menghitung jumlah koloni.

Pada proses klasifikasi menggunakan metode $K$-Nearest Neighbour, algoritma supervised learning yang terdiri dari input dan output, yang mana hasil dari instance yang baru diklasifikasikan berdasarkan similaritas dari kategori $K$ Nearest Neighbour. Tujuan dari metode algoritma ini untuk mengklasifikasikan obyek baru berdasarkan atribut dari sample-sample data training KNN menggunakan klasifikasi tetangga terdekat sebagai nilai prediksi dari nilai instance yang baru.

[Figure 4 about here.]

Untuk mempersingkat, ditemtukan 3 nilai petunjuk parameter pengklasifikasian yaitu 'kel' untuk menunjukkan nilai rata-rata keliling setiap object, 'lu' untuk rata-rata luas object, dan 'jum' untuk jumlah object. Ketiga parameter tersebut digunakan untuk perhitungan perbandingan similaritas dengan object. Kemudian dilakukan penghitungan jarak tiap object dengan dataset untuk menemukan nilai kesamaan atau pendekatan kemiripannya. Setelah ditemukan object memiliki kemiripan dengan dataset yang mana sejumlah $\mathrm{k}$ menggunakan Euclidean distance 3 parameter, ditemukan data yang paling sering muncul dengan object. Sehingga dapat diambil keputusan object tersebut teridentifikasi dan terklasifikasi sesuai dataset yang mana. Jumlah $\mathrm{K}$ dan rumus distance dari data pengujian dtentukan dari 4 rumus perhitungan jarak $\mathrm{k}$ terdekat menggunakan rumus Manhattan, Chebyshev, Euclidean Distance, dan Minkownski.

Manhattan

$\mathrm{D}(\mathrm{a}, \mathrm{b})=\left|a_{1}-b_{2}\right|+\cdots+\left|a_{n}-b_{n}\right|$

(1)

Chebyshev

$\mathrm{D}(\mathrm{a}, \mathrm{b})=\max \left(\left|a_{1}-b_{2}\right|+\cdots+\left|a_{n}-b_{n}\right|\right)$ 


\section{Euclidean Distance}

$\mathrm{D}(\mathrm{a}, \mathrm{b})=$

$\sqrt{\left(a_{1}-b_{1}\right)^{2}+\left(a_{2}-b_{2}\right)^{2}+\cdots+\left(a_{n}-b_{n}\right)^{2}}$

Minkownski

$\mathrm{D}(\mathrm{a}, \mathrm{b})=$

$\sqrt[p]{\left(a_{1}-b_{1}\right)^{p}+\left(a_{2}-b_{2}\right)^{p}+\cdots+\left(a_{n}-b_{n}\right)^{p}}$

Keterangan:

$\mathrm{D}(\mathrm{a}, \mathrm{b})$ :jarak dari kedua parameter $\mathrm{a}$ dan $\mathrm{b}$.

a nilai dataset.

b :nilai test objek.

$\mathrm{k}$ :jumlah data set yang akan dibandingkan similaritasnya dengan objek tes.

Pemrogaman yang digunakan pada sistem ini adalah pemrogaman python.

\subsection{Perangkat Keras}

[Figure 5 about here.]

\section{Lensa Okuler}

Lensa okuler merupakan lensa yang paling dekat dengan webcam. Dalam hal ini lensa okuler merupakan letak tabung kamera diletakkan dan perbesaran yang digunakan adalah $15 \mathrm{X}$.

2. Tabung Mikroskop

Tabung mikroskop berfungsi sebagai penghubung antara lensa okuler dengan lensa objektif.

3. Pemutar Kasar

Pemutar berfungsi sebagai pemutar lensa objektif mana yang akan digunakan.

4. Lensa Objektif

Lensa objektif merupakan lensa yang letaknya paling dekat dengan objek yang diamati. Fungsinya memperbesar bayangan benda objek dengan perbesaran 10x,40x, atau 100x.

5. Lengan Mikroskop

Lengan mikroskop berfungsi sebagai pegangan mikroskop ketika akan diangkat atau dipindahkan.

6. Meja Preparat

Meja Preparat berfungsi sebagai papan meja tempat diletakkannya preparat glass objek.

7. Pemutar kasar

Pemutar kasar terletak di lengan mikroskop. Pemutar ini berfungsi untuk memperjelas bayangan objek sekaligus mendekatkan meja preparat dengan lensa objektif.

8. Diagfragma

Diagfragma terletak tepat dibawah meja preparat. Diagframa berfungsi untuk mengatur jumlah cahaya yang masuk.

9. Sumber Cahaya

Sumber cahaya pada mikroskop ini menggunakan LED yang diatur terang dan gelapnya menggunakan variable resistor.

10. Penjepit Preparat

Penjepit ini berfungsi untuk mengkokohkan preparat glass yanbg diletakkan pada meja preparat agar tidak bergeser atau bergerak.

11. Motor Stepper
Motor stepper pada rangkaian alat ini berfungsi untuk memutar pemutar kasar pada mikrokop.

12. Box letak mikro dan board motor stepper Box ini terletak disebelah mikroskop. Berfungsi sebagai tempat penyimpanan board motor stepper ULN2003 dan mikrokontroller..

\section{HASIL DAN PEMBAHASAN}

[Figure 6 about here.]

Pada gambar 6. ditunjukkan tampilan awal GUI pada program identifikasi dan klasifikasi bakteri patogen dengan metode $k$-nearest neighbor. Pada tampilan ini kamera pada mikroskop belum diberikan perintah untuk menyala sehingga tertulis 'KAMERA MATI' pada tampilan GUI. Setelah menyala gambar dari mikroskop akan tampil pada kolom 'KAMERA MIKROSKOP', dan gambar hasil capture terbaik tampil pada kolom 'PROSES' menandakan gambar tersebut yang akan diproses untuk diidentifkasi dan diklasifikasi jenisnya berdasarkan parameter yang telah ditentukan. Pada kolom hasil akan menampilkan data gambar proses yang telah terlabel dan dihitung jumlah koloninya. Sehingga menghasilkan keputusan bakteri apa yang terindetifkasi menurut parameter yang ada pada gambar tersebut, dan ditampilkan pada kolom 'KEPUTUSAN'.

1. Berikan perintah untuk menyalakan kamera dengan klik button 'ON Kamera'.

2. Terlihat kolom kamera terisi gambar dari kamera dan siap memproses untuk selanjutnya dilakukan capture dan memilih hasil capture terbaik untuk diproses.

3. Untuk memulai proses autofocus pada mikroskop dan pengambilan capture, klik button 'START' sebagai tanda memulai proses awal image processing. Setelah kamera mengambil capture, dan ditemukan data gambar terbaik untuk diproses.

4. Gambar akan muncul pada kolom 'PROSES' untuk selanjutnya dilakukan image processing, diproses sesuai parameter yang ditentukan, dan diberikan label dengan klik button 'PROSES'. Setelah menekan button 'PROSES'.

5. Data gambar hasil capture akan diproses dan ditampilkan pada kolom 'Hasil', dan didapat keputusan yang ditampilkan seperti dibawah ini.

[Figure 7 about here.]

Dataset yang diambil pada penelitian ini terdiri dari 114 dataset dari 3 bakteri. Berikut sebagian dataset sebagai inputan untuk data pengolahan pada K-Nearest Neighbour.

[Table 1 about here.]

Untuk menemukan akurasi terbaik dari $K$-Nearest Neighbour dilakukan perbandingan empat rumus yaitu Euclidean, Manhattan, Chebyshev, dan Minkowski. Dari setiap rumus ditentukan akurasinya hingga didapat rumus perhitungan jarak terbaik dari tetangga terdekat.

Keterangan:

PIC1 = Bakteri Vibrio Chlorae

PIC2 = Bakteri Staphylococcus A.

PIC3 = Bakteri Streptococcus $m$. 


\subsection{Euclidean Distance}

Diambil masing-masing 15 data gambar dari setiap jenis bakteri. Ditemukan $\sum$ data diprediksi tepat sebagai berikut.

Diketahui hasil perhitungan Euclidean Distance dengan $\mathrm{K}=3$ untuk data benar= 39 dan data salah sebanyak 6 . Kemudian dihitung cross validation sebagai berikut.

Persentasi akurasi $=\frac{39}{45} \times 100 \%=86.67 \%$

Diketahui hasil perhitungan Euclidean Distance dengan $\mathrm{K}=5$ untuk data benar $=42$ dan data salah sebanyak 3 . Kemudian dihitung cross validation sebagai berikut.

Persentasi akurasi $=\frac{42}{45} \times 100 \%=93.33 \%$

Diketahui hasil perhitungan Euclidean Distance dengan $\mathrm{K}=7$ untuk data benar= 43 dan data salah sebanyak 2 . Kemudian dihitung cross validation sebagai berikut.

$$
\text { Persentasi akurasi }=\frac{43}{45} \times 100 \%=95.56 \%
$$

Diketahui hasil perhitungan Euclidean Distance dengan $\mathrm{K}=9$ untuk data benar= 41 dan data salah sebanyak 4 . Kemudian dihitung cross validation sebagai berikut.

$$
\text { Persentasi akurasi }=\frac{41}{45} \times 100 \%=91.11 \%
$$

Dari hasil perhitungan diatas dengan $\mathrm{K}=3$, tabel 4.3 dengan $\mathrm{K}=5, \mathrm{~K}=7$, dan $\mathrm{K}=9$ pada rumus Euclidean Distance diketahui $\mathrm{k}$ terbaik adalah 7 dengan akurasi sebesar $95.55 \%$.

\subsection{Chebyshev}

Diambil masing-masing 15 data gambar dari setiap jenis bakteri. Ditemukan $\sum$ data diprediksi tepat sebagai berikut.

Diketahui hasil perhitungan Chebyshev dengan $\mathrm{K}=3$ untuk data benar $=42$ dan data salah sebanyak 3 . Kemudian dihitung cross validation sebagai berikut.

$$
\text { Persentasi akurasi }=\frac{42}{45} \times 100 \%=93.33 \%
$$

Diketahui hasil perhitungan Chebyshev dengan $\mathrm{K}=5$ untuk data benar $=44$ dan data salah sebanyak 1 . Kemudian dihitung cross validation sebagai berikut.

Persentasi akurasi $=\frac{44}{45} \times 100 \%=97.77 \%$

Diketahui hasil perhitungan Chebyshev dengan $\mathrm{K}=7$ untuk data benar $=42$ dan data salah sebanyak 3 . Kemudian dihitung cross validation sebagai berikut.

Persentasi akurasi $=\frac{42}{45} \times 100 \%=93.33 \%$

Diketahui hasil perhitungan Chebyshev dengan $\mathrm{K}=9$ untuk data benar $=41$ dan data salah sebanyak 4 . Kemudian dihitung cross validation sebagai berikut.

Persentasi akurasi $=\frac{41}{45} \times 100 \%=91.11 \%$

Dari hasil perhitungan diatas dengan $\mathrm{K}=3, \mathrm{~K}=5, \mathrm{~K}=7$, dan $\mathrm{K}=9$ pada rumus Euclidean Distance diketahui k terbaik adalah 5 dengan akurasi sebesar $97.77 \%$.

\subsection{Manhattan}

Diambil masing-masing 15 data gambar dari setiap jenis bakteri. Ditemukan $\sum$ data diprediksi tepat sebagai berikut.
Diketahui hasil perhitungan Manhattan dengan $\mathrm{K}=3$ untuk data benar $=39$ dan data salah sebanyak 5 . Kemudian dihitung cross validation sebagai berikut.

$$
\text { Persentasi akurasi }=\frac{39}{45} \times 100 \%=86.67 \%
$$

Diketahui hasil perhitungan Manhattan dengan $\mathrm{K}=5$ untuk data benar= 40 dan data salah sebanyak 5. Kemudian dihitung cross validation sebagai berikut.

$$
\text { Persentasi akurasi }=\frac{40}{45} \times 100 \%=88.89 \%
$$

Diketahui hasil perhitungan Manhattan dengan $\mathrm{K}=7$ untuk data benar $=44$ dan data salah sebanyak 1 . Kemudian dihitung cross validation sebagai berikut.

$$
\text { Persentasi akurasi }=\frac{44}{45} \times 100 \%=97.77 \%
$$

Diketahui hasil perhitungan Manhattan dengan $\mathrm{K}=9$ diketahui data benar $=40$ dan data salah sebanyak 5 . Kemudian dihitung cross validation sebagai berikut.

$$
\text { Persentasi akurasi }=\frac{40}{45} \times 100 \%=88.89 \%
$$

Dari hasil perhitungan diatas dengan $\mathrm{K}=3, \mathrm{~K}=5, \mathrm{~K}=7$, dan $\mathrm{K}=9$ pada rumus Manhattan Distance diketahui k terbaik adalah 7 dengan akurasi sebesar $97.77 \%$.

\subsection{Minkowski}

Diambil masing-masing 15 data gambar dari setiap jenis bakteri. Ditemukan $\sum$ data diprediksi tepat sebagai berikut.

Diketahui hasil perhitungan Minkowski dengan $\mathrm{K}=3$ untuk data benar $=41$ dan data salah sebanyak 4. Kemudian dihitung cross validation sebagai berikut.

$$
\text { Persentasi akurasi }=\frac{41}{45} \times 100 \%=91.11 \%
$$

Diketahui hasil perhitungan Minkowski dengan $\mathrm{K}=5$ untuk data benar $=43$ dan data salah sebanyak 2 . Kemudian dihitung cross validation sebagai berikut.

$$
\text { Persentasi akurasi }=\frac{43}{45} \times 100 \%=95.55 \%
$$

Diketahui hasil perhitungan Minkowski dengan $\mathrm{K}=7$ untuk data benar $=42$ dan data salah sebanyak 3 . Kemudian dihitung cross validation sebagai berikut.

$$
\text { Persentasi akurasi }=\frac{42}{45} \times 100 \%=93.33 \%
$$

Diketahui hasil perhitungan Minkowski dengan $\mathrm{K}=9$ untuk data benar $=41$ dan data salah sebanyak 4 . Kemudian dihitung cross validation sebagai berikut.

$$
\text { Persentasi akurasi }=\frac{41}{45} \times 100 \%=91.11 \%
$$

Dari hasil perhitungan dengan $\mathrm{K}=3, \mathrm{~K}=5, \mathrm{~K}=7$, dan $\mathrm{K}=9$ pada rumus Minkowski Distance diketahui k terbaik adalah 5 dengan akurasi sebesar $95.55 \%$. 


\section{KESIMPULAN}

Berdasarkan hasil perancangan, implementasi, dan pengujian sistem, maka dapat ditarik kesimpulan sebagai berikut:

1. Proses learning untuk mendapatkan dataset memerlukan banyak pengambilan citra. Faktor perlakuan kepada bakteri untuk diletakkan pada preparat, gelap dan terang cahaya pada saat testing mempengaruhi pengambilan keputusan. Perlakuan dan tata cahaya yang berbeda ketika pengambilan dataset dan test yang berbeda mempengaruhi akurasi pengambilan keputusan sehingga kurang akurat.

2. Pada proses klasifikasi nilai tetangga terdekat atau $\mathrm{K}$ dengan akurasi paling baik adalah $\mathrm{K}=5$ dengan metode Chebyshev yang nilai akurasi terkecilnya $91.11 \%$ pada $\mathrm{K}=9$ dan akurasi terbesar $97.77 \%$.

3. Semakin banyak jenis bakteri yang akan diuji mempengaruhi tingkat akurasi proses klasifikasi KNN.

\section{UCAPAN TERIMA KASIH}

Terima kasih kepada Universitas Muhammadiyah Sidoarjo yang telah mengizinkan jurnal saya untuk terbit di halaman OJS JEEE. Semoga jalinan partisipasi dan kontribusi ini beriringan dan berlanjut di masa yang akan datang.

\section{REFERENSI}

[1] M. V Holderman, E. De Queljoe, S. B. Rondonuwu, and P. S. Biologi, "Identification Of Bacteria In Handrail Escalator on," J. Ilm. Sains, vol. 17, no. 1, pp. 13-18, 2017.

[2] A. Nuryah, N. Yuniarti, and I. Puspitasari, "Prevalensi dan Evaluasi Kesesuaian Penggunaan Antibiotik pada Pasien dengan Infeksi Methicillin Resistant Staphylococcus Aureus di RSUP Dr. Soeradji Tirtonegoro Klaten," Maj. Farm., vol. 15, no. $2, \quad$ p. $123, \quad 2019$, doi: 10.22146/farmaseutik.v15i2.47911.

[3] H. Tolle, "Klasifikasi dan Identifikasi Jumlah Koloni," vol. 8, no. 2, pp. 78-82, 2016.

[4] E. Priyanti, "Penerapan Algoritma Naïve Bayes Untuk Klasifikasi Bakteri Gram-Negatif," J. Tek. Komput., vol. III, no. 2, pp. 68-76, 2017.

[5] M. F. Wahid, T. Ahmed, and M. A. Habib, "Classification of microscopic images of bacteria using deep convolutional neural network," ICECE 2018 - 10th Int. Conf. Electr. Comput. Eng., pp. 217-220, 2019, doi: 10.1109/ICECE.2018.8636750.

[6] B. D. Satoto, I. Utoyo, and R. Rulaningtyas, "Colour segmentation of Gram-Negative bacteria using graph Quadratic Form and Random Walker," J. Phys. Conf. Ser., vol. 1538, no. 1, pp. 0-8, 2020, doi: 10.1088/1742-6596/1538/1/012005

[7] J. R. Balbin, J. T. Sese, C. V. R. Babaan, D. M. M. Poblete, R. P. Panganiban, and J. G. Poblete, "Detection and classification of bacteria in common street foods using electronic nose and support vector machine," Proc. - 7th IEEE Int. Conf. Control Syst. Comput. Eng. ICCSCE 2017, vol. 2017-Novem, no. November, pp. 247-252, 2018, doi: 10.1109/ICCSCE.2017.8284413.

[8] T. Treebupachatsakul and S. Poomrittigul, "Bacteria Classification using Image Processing and Deep learning," 34th Int. Tech. Conf. Circuits/Systems, Comput. Commun. ITC-CSCC 2019, pp. 2-4, 2019, doi: 10.1109/ITCCSCC.2019.8793320.

[9] A. S. Lee et al., "Methicillin-resistant Staphylococcus aureus," Nat. Rev. Dis. Prim., vol. 4, no. May, pp. 1-23, 2018, doi: 10.1038/nrdp.2018.33.

[10] J. A. Lemos et al., "The Biology of Streptococcus mutans," Microbiol. Spectr., vol. 7, no. 1, pp. 1618, 2019, doi: 10.1128/microbiolspec.gpp3-00512018.

[11] D. Domman et al., "the Americas," vol. 793, no. November, pp. 789-793, 2017.

[12] K. Neighbor, E. Distance, and P. Gambar, "Buku TA : K-Nearest Neighbor ( KNN ),” no. x, 2010.

[13] T. M. Cover and P. E. Hart, "Nearest Neighbor Pattern Classification," IEEE Trans. Inf. Theory, vol. 13, no. 1, pp. 21-27, 1967, doi: 10.1109/TIT.1967.1053964.

[14] W. Wahyono, I. N. P. Trisna, S. L. Sariwening, M. Fajar, and D. Wijayanto, "Comparison of distance measurement on k-nearest neighbour in textual data classification," J. Teknol. dan Sist. Komput., vol. 8, no. 1, pp. 54-58, 2020, doi: 10.14710/jtsiskom.8.1.2020.54-58.

[15] B. P. Citra, E. Marliana, and A. Wahjudi, "Rancang Bangun Perangkat Lunak Unit Kontrol Alat Ukur Sudu Cross Flow Water Turbine," vol. 3 , no. 2, 2014 .

[16] A. F. Ibadillah, "Sistem Penjejakan Obyek Dengan Stero Vision."

[17] M. Z. Arifin, K. Joni, M. Ulum, T. Elektro, and U. Trunojoyo, "Penentuan Kualitas Warna Batu Blue Sapphire Dengan Image Processing Menggunakan Metode RGB To HSV," vol. 1003051623, pp. 5963.

[18] M. Z. Arifin, K. Joni, M. Ulum, T. Elektro, and U. Trunojoyo, "Penentuan Kualitas Warna Batu Blue Sapphire Dengan Image Processing Menggunakan 
Metode RGB To HSV,” vol. 1003051623, pp. 59-

63.

Conflict of Interest Statement: The author declares that the research was conducted in the absence of any commercial or financial relationships that could be construed as a potential conflict of interest.

Copyright (C) 2021 Author [s]. This is an open access article distributed un- der the terms of the Creative Commons Attribution License (CC $\mathrm{BY})$. The use, distribution or reproduction in other forums is permitted, provided the original author(s) and the copyright owner(s) are credited and that the original publication in this journal is cited, in accordance with accepted academic practice. No use, distribution or reproduction is permitted which does not comply with these terms.

Received: 2021-01-30

Accepted: 2021-02-06

Published: 2021-04-0 
$\sqrt{\mathrm{A}} \sqrt{\mathrm{A}} \sqrt{\mathrm{A}} \square \mathrm{C} \begin{aligned} & \text { Journal of Electrical and Electronic Engineering-UMSIDA } \\ & \text { ISSN 2460-9250 (print), ISSN 2540-8658 (online) }\end{aligned}$

Vol. 5, No. 1, April 2021

DAFTAR TABEL

I Tabel dataset Bakteri 
Table I. Tabel dataset Bakteri

\begin{tabular}{|r|c|c|c|c|}
\hline No. & $\begin{array}{c}\text { Keliling } \\
\text { (pixel) }\end{array}$ & $\begin{array}{c}\text { Luas } \\
\text { (pixel) }\end{array}$ & $\begin{array}{c}\text { Jumlah } \\
\text { koloni }\end{array}$ & $\begin{array}{c}\text { Nama } \\
\text { PIC }\end{array}$ \\
\hline 1. & 63.49975998 & 268.5567 & 117 & PIC1 \\
\hline 2. & 79.61625061 & 614.8966 & 37 & PIC1 \\
\hline 3. & 100.0542357 & 859.8804 & 61 & PIC1 \\
\hline 4. & 85.4060074 & 530.8364 & 74 & PIC1 \\
\hline 5. & 128.9348639 & 1433.643 & 51 & PIC1 \\
\hline 6. & 19.43836473 & 15.84043 & 158 & PIC2 \\
\hline 7. & 22.67344596 & 35.85751 & 205 & PIC2 \\
\hline 8. & 17.53878245 & 13.17204 & 111 & PIC2 \\
\hline 9. & 24.3087722 & 41.54524 & 232 & PIC2 \\
\hline 10. & 27.17641937 & 50.85811 & 179 & PIC2 \\
\hline 11. & 27.1062737 & 100.4472 & 175 & PIC3 \\
\hline 12. & 33.32823666 & 93.31793 & 206 & PIC3 \\
\hline 13. & 24.53504101 & 116.1316 & 172 & PIC3 \\
\hline 14. & 29.59455509 & 179.8862 & 135 & PIC3 \\
\hline 15. & 31.04430189 & 126.0345 & 165 & PIC3 \\
\hline
\end{tabular}




\section{DAFTAR GAMBAR}

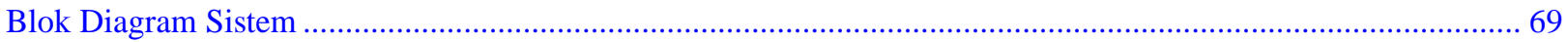

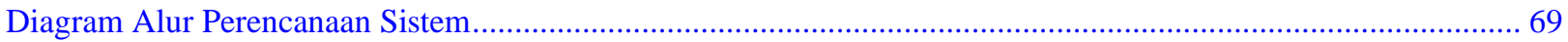

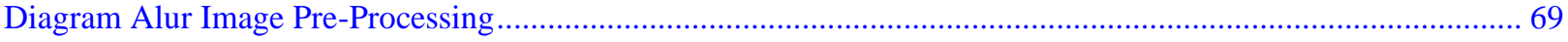

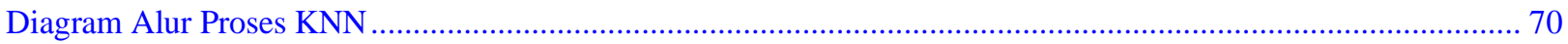

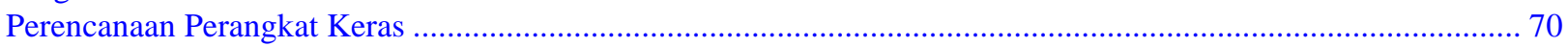

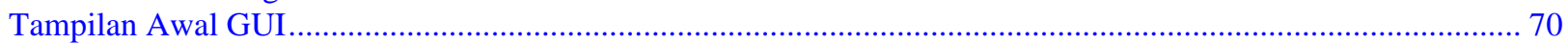

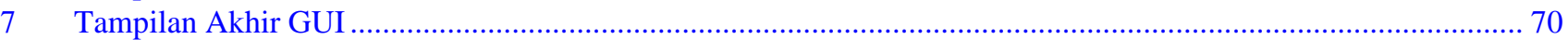




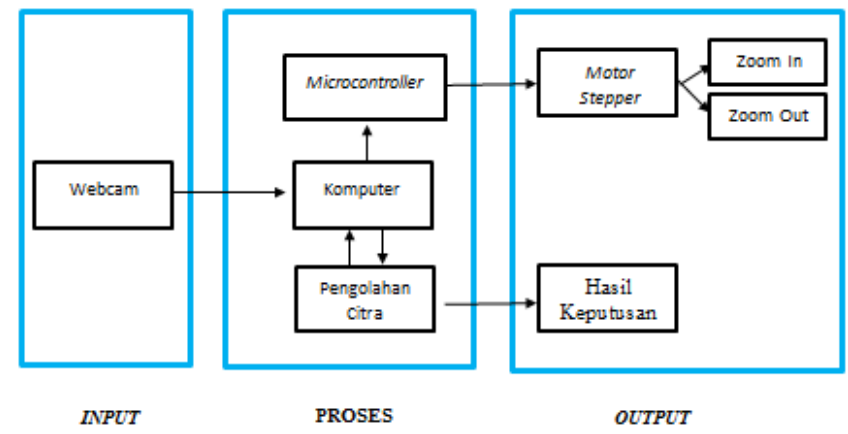

Figure 1. Blok Diagram Sistem

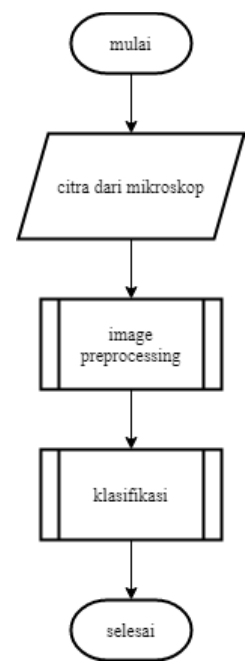

Figure 2. Diagram Alur Perencanaan Sistem

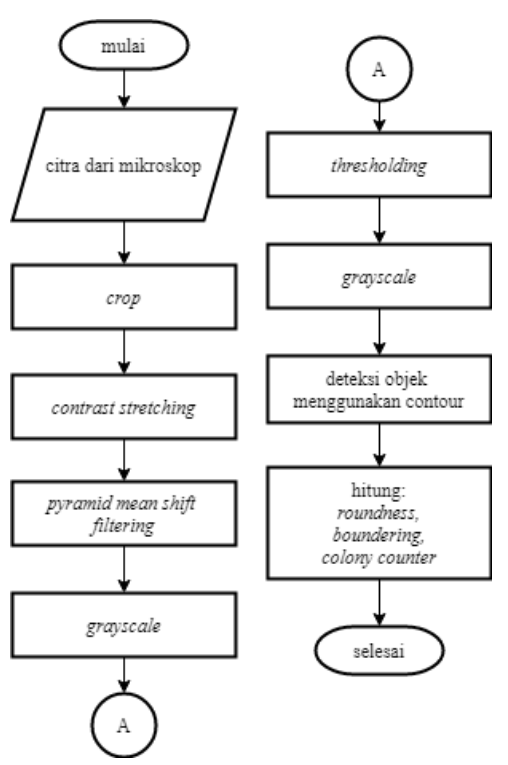

Figure 3. Diagram Alur Image Pre-Processing 


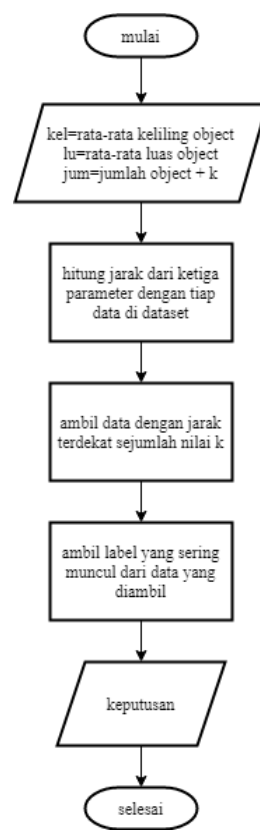

Figure 4. Diagram Alur Proses KNN

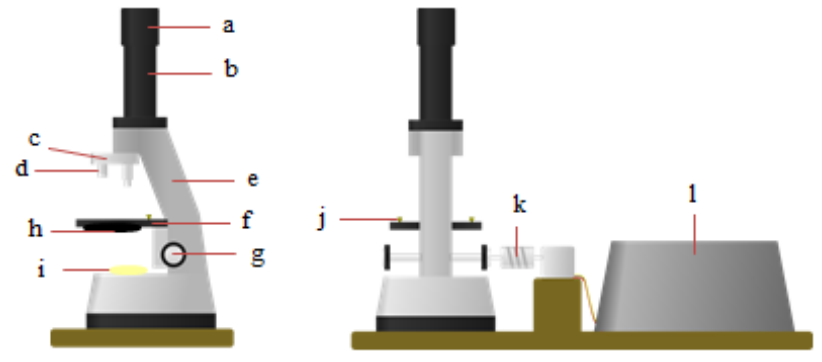

Figure 5. Perencanaan Perangkat Keras

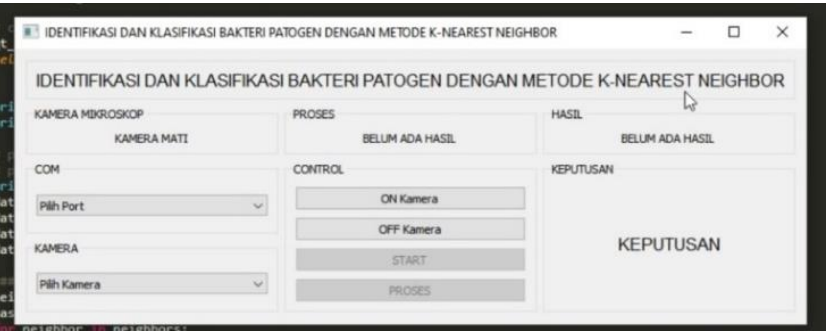

Figure 6. Tampilan Awal GUI

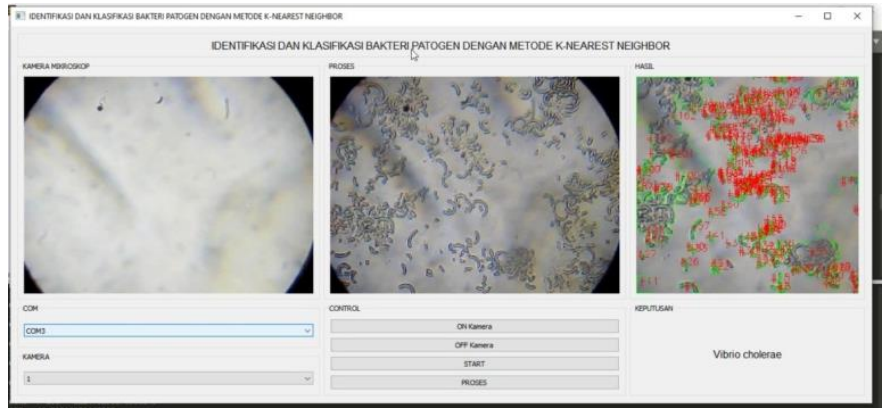

Figure 7. Tampilan Akhir GUI 